\section{Election further postpones the decision on UK space plans}

\section{London}

THE long-awaited decision on the British national space plan has been further delayed with the announcement of the general election. The British National Space Centre (BNSC), which last September prepared the 15-year plan at the request of the government, does not now expect a decision until "well into July at the earliest".

The protracted deliberations are causing frustration among BNSC staff and the British space community, who are finding it difficult to formulate long-term research strategies. The speediest solution likely would arise if the Conservative government is returned and if the ministers involved in the original decision-making are retained; if different ministers are appointed, a briefing period, likely to take several weeks, would be necessary.

Given the length of time it is taking for a decision to be made, Britain is fortunate that a ministerial council meeting of the European Space Agency (ESA), originally suggested for next month, is not now likely to be held until November, and BNSC makes no secret of its relief. Roy Gibson, director general of BNSC, says that a decision on the plan is essential for BNSC if it is to retain credibility during negotiations around the ESA table, "particularly as we frequently lead the charge for realism in the costing and time schedules of the new large programmes. What remains of diplomatic courtesy has so far discouraged our friends in Europe from asking whether the United Kingdom's financial contribution is worth the trouble we are causing, but it has come very close once or twice."

The proposed space plan has not been published and BNSC will not indicate how

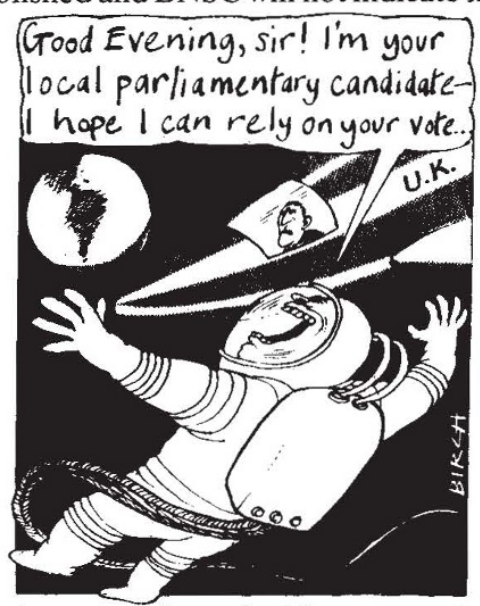

much money it has asked for, except that it is a "significant increase" on the present budget of around $£ 110$ million, of which 80 per cent goes to ESA. Informed estimates suggest that a figure of around $£ 300 \mathrm{mil}-$ lion a year is realistic, given that BNSC is to double its ESA contribution over the next three years and that the plan proposes to increase the proportion of the domestic space programme from 20 per cent of the total spend to nearer 40 per cent.

Simon Hadlington

\section{Ariane's new schedule for keeping ahead}

Paris

Almost exactly a year after a third-stage ignition failure forced the destruction of the European space rocket, Ariane 2, Arianespace has issued its new launch schedule. The next launch, V19, is now planned for August 1987, if the June trials of the modified third-stage liquid hydrogen-oxygen engine are successful.

If Ariane is given a clean bill of health in June, three launches will be carried out in 1987, eight in 1988 and nine in 1989 and 1990. As Ariane can launch two satellites on one rocket, Arianespace is optimistic that it will be able to make up for lost time. The backlog of orders stands at 46 satellites, worth an estimated $\mathbf{\$ 2 , 4 5 0}$ million, of which 21 are from European customers, 9 from the United States, 10 from international companies and the remaining 6 from Canada, India, Japan and Australia.

The sudden halt to the Ariane launch schedule last May prevented the European company from taking full advantage of the gap in the market opened by the problems that had halted shuttle launches. Despite a full order book, Arianespace has had to watch its lead be whittled away as the Soviet Union, China and Japan prepare to enter the commercial market. But Frédéric d'Allest, chief executive officer of Arianespace, feels that Europe has time on its side. In Washington last week d'Allest said that "there is no real threat from China until 1992 at the earliest. The Japanese $\mathrm{H}-2$ rocket is capable of launching medium-sized satellites, but will not be ready until 1994."

The accidents to Ariane 2 and Challenger in 1986 followed a loss to the space insurance market in 1985 exceeding $\$ 400$ million - twice the revenue collected from insurance premiums in the previous 13 years. Today, almost half of the cost of launching a class $1 / 2$ Ariane 3 satellite is to cover insurance. In January 1986 Arianespace set up a wholly-owned insurance subsidiary to cover launch-phase risks in an attempt to keep down the total cost to the customer.

\section{Caesium limits a hot issue}

\section{London}

NEW limits on radioactivity in food proposed last week by the European Commission could prove a political hot potato. Scientific advice on acceptable caesium levels has been ignored, and the proposed limits seem unlikely to be supported by all member countries.

The European Commission's proposed maximum permissible limits for radioactive contamination of food and drinking water would be introduced as part of a permanent safeguard system to be operated in the event of a nuclear accident, and would replace the emergency limits introduced in the aftermath of the Chernobyl accident. The emergency limits expire on 31 October.

Advice sought from scientists and public health experts who make up the socalled Article 31 Committee of Euratom was accepted for isotopes of plutonium, iodine and strontium, but the Commission sharply reduced the figures for caesium. For caesium the Commission is recommending a limit of 1,000 bequerels per kilogram or litre for dairy products, 1,250 for other foodstuffs, 800 for drinking water, and 2,500 for animal feedstocks. The Article 31 experts had suggested 4,000 for dairy products and 5,000 for other foods.

The Commission explained that some countries outside the European Economic Community (EEC) are applying strict levels that could pose problems for Community exporters. "The levels chosen should command public confidence", a briefing paper explained. But the proposals have been criticized by the director of Britain's National Radiological Protection Board, Dr John Dunster, a member of the Article 31 Committee. "I don't think low levels command public confidence, especially when you muck about with the figures", he said. But, Dunster added, "it is legitimate for scientific advice given to a political body to be rejected on political grounds".

The Article 31 Committee last year made "reasonable guesses" which led to recommended caesium limits of 30,000 becquerels per kilogram, according to Dunster, but the Commission staff cut the level back to 9,000 to allow for additivity. The final post-Chernobyl limits adopted were 600 for dairy products and 370 for other food imported into the EEC. The limits within Britain were set at 1,000.

"The Commission has chickened out", Dunster said. "But if they think 1,000 and 1,250 will be better for trade and public opinion, it's their judgement - but it's not supported by the scientific advice."

Kathy Johnston 